\title{
SCREENING AND EVALUATION OF SECONDARY METABOLITES PRESENT IN PIPER CUBEBA
}

\author{
NIRMALA NITHYA R*, SAI NANDHINI R \\ Department of Biotechnology, Vel Tech Rangarajan Dr. Sagunthala R\&D Institute of Science and Technology, Chennai, Tamil Nadu, India. \\ Email: nirmalanithya@veltech.edu.in
}

Received: 23 August 2019, Revised and Accepted: 21 October 2019

\section{ABSTRACT}

Objective: Bioactive compounds like phytochemicals are extracted mainly from plants, as they serve as traditional herbal medicine. The secondary metabolite such as alkaloids, flavonoids, and phenolic compounds serve as natural antioxidants and has been widely used due to its therapeutic applications. The objective of this study was to do preliminary phytochemical screening of the spice Piper cubeba.

Methods: Totally, three solvents were used to prepare the extract. Of all the three extracts used, methanolic extract showed higher release of secondary metabolites when compared to ethyl acetate and hexane extract. Further quantitative analysis was carried out with the methanolic extract.

Results: The presence of alkaloids, flavonoids, phenolic compounds, and tannins was observed. A significant result such as $1040 \mu \mathrm{g}$ of Gallic acid equivalent/g of total concentration of flavonoid and $1280 \mu \mathrm{g}$ of quercetin equivalent/g of total phenolic content was obtained.

Keywords: Secondary metabolite, Alkaloid, Flavonoid, Phenolic content.

(C) 2019 The Authors. Published by Innovare Academic Sciences Pvt Ltd. This is an open access article under the CC BY license (http://creativecommons. org/licenses/by/4. 0/) DOI: http://dx.doi.org/10.22159/ajpcr.2019.v12i12.35436

\section{INTRODUCTION}

Plants are regarded as the richest resource for many potential drugs. Although usage of plants as medicine has been known for millennia, its therapeutic value is gaining significance in recent years [1-3]. Natural antioxidants such as spices and herbs help to prevent the disease and cure various ailments [4-6].

The secondary metabolites produced by plants exhibit various structural diversity, which is found to be biologically active. These include a wide set of products such as alkaloids, steroids, tannins, phenols, glycosides, and flavonoids $[3,7,8]$. One such therapeutically significant medicinal plant Piper cubeba belongs to the Piperaceae family; it has more than 700 species distributed in the tropical and subtropical regions of the world. It has many therapeutic uses and can be used as diuretic, hepatoprotective, antipyretic, and antioxidant [9]. Bronchitis and other associated ailments can be treated by this plant. Furthermore, it is used to treat paralysis and rheumatism. This present study evaluates and analyses the existence of huge secondary metabolites in the seeds of P. cubeba.

\section{METHODS}

\section{Collection of plant materials}

$P$. cubeba seeds were collected from local market and shade dried at room temperature (RT) for a week. Dried seeds were blended to a fine powder and stored in an airtight container at RT.

\section{Preparation of plant extract}

The powdered plant material was extracted with methanol, ethyl acetate, and hexane in the ratio of 1:10 and kept in shaking condition for 24 h. The extract was filtered using Whatman No. 1 filter paper. The process was reciprocated using the same plant material thrice by changing the solvent. The combined filtrate was subjected to condensation. The extracts were placed in the distillation unit to separate the solvent [10]. The separated residues were redissolved in different solvents to get a yield $10 \mathrm{mg} / \mathrm{ml}$ solutions for future work.
Phytochemical screening

Qualitative analysis

Detection of alkaloids

A few ml of dilute hydrochloric (HCL) was added in $50 \mathrm{mg}$ of extract and filtered. The extracted filtrates were used for Mayer's test to identify the presence of alkaloids.

Mayer's test

Mayer's reagent was added to the few $\mathrm{ml}$ of extracted filtrate along the sides of the test tube. A white creamy precipitate indicated the presence of alkaloids.

Mayer's reagent

About $5 \mathrm{~g}$ of potassium chloride and $1.358 \mathrm{~g}$ of mercuric chloride was dissolved in $10 \mathrm{ml}$ and $60 \mathrm{ml}$ of water. Both the solutions were mixed and made up to final volume of $100 \mathrm{ml}$ with water.

\section{Detection of phenolic compound}

Ferric chloride test

About $50 \mathrm{mg}$ of the extract was dissolved in $5 \mathrm{ml}$ of distilled water. To the mixture, 4-5 drops of 5\% neutral ferric chloride solution were added. The presence of phenolic compounds was identified by the formation of a dark green color.

Detection of glycosides

About $50 \mathrm{mg}$ of the extract was mixed with concentrated HCL acid and hydrolyzed for $2 \mathrm{~h}$ in a water bath, and the filtered hydrolyses were used for following test.

\section{Borntrager's test}

About $2 \mathrm{ml}$ of the filtrate was added to $3 \mathrm{ml}$ of chloroform and shake well. Chloroform layer should be separated and $10 \%$ of ammonia solution was added. Formation of pink color indicates the presence of glycosides.

\section{Detection of flavonoids}

A few $\mathrm{ml}$ of extract was added with $10 \mathrm{ml}$ of ethyl acetate and heated in a steam bath for $3 \mathrm{~min} .4 \mathrm{ml}$ of the filtrate was mixed with $1 \mathrm{ml}$ of dilute 
ammonia solution and shaken well to form a yellow color appearance for the presence of flavonoids.

\section{Detection of tannins}

In a test tube, take $2 \mathrm{ml}$ of the extract and mix with $2 \mathrm{ml}$ of distilled water, with that few drops of $0.1 \% \mathrm{FeCl}_{3}$ solution were added. Green precipitation was formed and indicated the presence of tannins.

\section{Detection of reducing sugars}

About $100 \mathrm{mg}$ of extract was stirred in $50 \mathrm{ml}$ of water and filtered. The filtrate was used for the following test.

Fehling's test

About $1 \mathrm{ml}$ of Fehling's solution I and II was mixed with $1 \mathrm{ml}$ of filtrate and kept in a water bath. Red color formation indicates the presence of sugar.

\section{Fehling's solution}

Fehling's solution I: About $34.66 \mathrm{~g}$ of copper sulfate was dissolved in distilled water and made up to $500 \mathrm{ml}$ with distilled water.

Fehling's solution II: About $173 \mathrm{~g}$ of potassium sodium tartrate and 50 g of sodium hydroxide was dissolved in water and made up to $500 \mathrm{ml}$.

\section{Detection of saponins}

Foam test

About $50 \mathrm{mg}$ of the extract was diluted and made up to $20 \mathrm{ml}$ with distilled water. It was shaken continuously for $15 \mathrm{~min}$. A foam layer was formed about $2 \mathrm{~cm}$ and it indicates the presence of saponins.

\section{Detection of proteins}

About $100 \mathrm{mg}$ of the extract was dissolved in $10 \mathrm{ml}$ of distilled water and filtered. The filtered extract was used for biuret test.

Biuret test

A drop of $2 \%$ copper sulfate solution was added to $2 \mathrm{ml}$ of filtrate and $1 \mathrm{ml}$ of ethanol (95\%) was added with excess of potassium hydroxide pellets. Pink color formation indicates the presence of protein

\section{Quantitative analysis}

Determination of total phenolic contents

Spectrophotometric method was used to determine the total phenolic concentration. Methanol solution of the extract in the concentration of $1 \mathrm{mg} / \mathrm{ml}$ was used in the analysis. A mixture was made using 0.5 $\mathrm{ml}$ methanol solution of extract and $2.5 \mathrm{ml}$ of $10 \%$ Folin-Ciocalteu's reagent dissolved in water followed by the addition of $2.5 \mathrm{ml} 7.5 \%$ $\mathrm{NaHCO}_{3}$. Blank was concomitantly prepared, containing $0.5 \mathrm{ml}$ methanol, $2.5 \mathrm{ml} 10 \%$ Folin-Ciocalteu's reagent dissolved in water, and $2.5 \mathrm{ml}$ of $7.5 \%$ of $\mathrm{NaHCO}_{3}$. Then, the samples were incubated at $45^{\circ} \mathrm{C}$ for $45 \mathrm{~min}$. The absorbance was determined using spectrophotometer at $765 \mathrm{~nm}$ [11]. The experiment was repeated thrice and the mean value of absorbance was obtained. The same procedure was repeated for the standard solution of Gallic acid and the calibration line was constructed. Depending on the absorbance value, the total phenolic content concentration was determined and was expressed in terms of Gallic acid equivalent (GAE) [12].

\section{Determination of flavonoid concentrations}

The content of flavonoids in the examined plant extracts was determined using spectrophotometric method. The sample contained $1 \mathrm{ml}$ of methanol solution of the extract in the concentration of $1 \mathrm{mg} / \mathrm{ml}$ and $1 \mathrm{ml}$ of $2 \% \mathrm{AlCl}_{3}$ solution dissolved in methanol. The samples were incubated for an hour at RT. The absorbance was determined using spectrophotometer at $\lambda_{\max }=415 \mathrm{~nm}$. The mean value of absorbance was obtained from the triplicate samples. The same procedure was repeated for the standard solution of quercetin and the calibration line was construed. Based on the measured absorbance, the total concentration of flavonoids was obtained from the measured absorbance and is expressed in terms of quercetin equivalent (QE) [12].

\section{RESULTS AND DISCUSSION}

Preliminary phytochemical constituents of $P$. cubeba leaves revealed the presence of secondary metabolites such as tannins, phenolic compounds, flavonoids, and alkaloids while glycosides, saponins, proteins, and reducing sugars were absent. The results are incorporated in Table 1.

On comparison with the methanol extracts, the plant extract of ethyl acetate and hexane shows minimum amount of secondary metabolites.

Alkaloids are mainly used for pain killer drug development, and it is largest group of phytochemicals in the plant [13]. It is reported that piperine is used in the treatment of anti-inflammatory, antimalarial, and antileukemia [4] and plays a major role in herbal cough syrups. Mostly, it helps to increase the absorption of selenium, vitamins, and carotene and also increase the body's natural thermogenic activity [14]. Methanolic extract of Piper nigrum has been administered to significantly improve memory performance and has exhibited antioxidant potential [15]. Since the methanolic extracts have shown good results, the quantitative analysis was carried out with that. In the quantitative analysis of

Table 1: Phytochemical screening of Piper cubeba using different extracts

\begin{tabular}{lllll}
\hline S. No. & Compound & Methanol & $\begin{array}{l}\text { Ethyl } \\
\text { acetate }\end{array}$ & Hexane \\
\hline 1. & Alkaloids & + & + & - \\
2. & Phenolic compounds & +++ & + & - \\
3. & Glycosides & - & - & - \\
4. & Flavonoids & +++ & + & + \\
5. & Tannins & + & - & - \\
6. & Reducing sugars & - & - & - \\
7. & Saponins & - & - & - \\
8. & Proteins & - & - & - \\
\hline+++ denotes highly present, + denotes mildly present and-denotes absence
\end{tabular}

Table 2: Phenol and flavonoid content of Piper cubeba in methanolic extracts

\begin{tabular}{lll}
\hline S. No. & Phytochemical present & Amount \\
\hline 1. & Total phenolic content & $1280(\mu \mathrm{g}$ of GAE/g of extract $)$ \\
2. & Total flavonoid content & $1040(\mu \mathrm{g}$ of $\mathrm{QE} / \mathrm{g}$ of extract $)$ \\
\hline
\end{tabular}

GAE: Gallic acid equivalent, QE: Quercetin equivalent

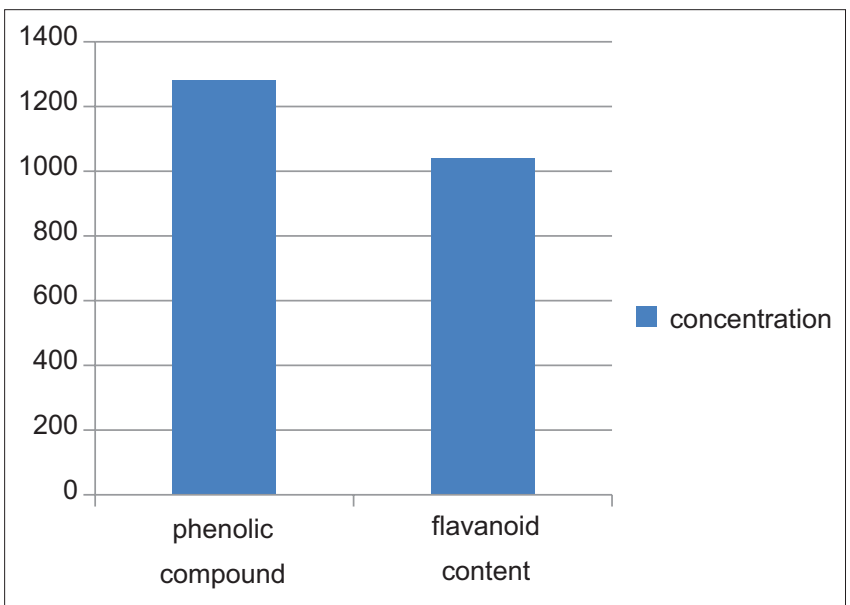

Fig. 1: Comparative study on phenolic and flavonoid content present in Piper cubeba 
P. cubeba, the total concentration of flavonoid was estimated to be $1040 \mu \mathrm{g}$ of GAE/g of extract and the total concentration of flavonoids was found to be $1280 \mu \mathrm{g}$ of QE/g of extract (Table 2).

The secondary metabolites such as phenolic compounds have high amount of antioxidant activity $[16,17]$. The results obtained in this study showed a significant level of phenolic compounds. Flavonoids are another class of secondary plant metabolites, also known as Vitamin P [18]. These metabolites are rich to produce yellow pigments and other coloration in plants. Flavonoids are absorbed by humans, and they seem to antiinflammatory, antiallergic, and anticancer activities [19]

From Fig. 1, it is evident that the phenolic contents are quite higher when compared with the flavonoid compounds.

\section{CONCLUSION}

The phytochemical screening indicates the presence of significant amount of alkaloids, phenolic compounds, tannins, and flavonoids in the crude methanolic extract. Many such compounds are known to possess high antioxidant activity. The higher amount of polyphenolic compound is evident to show higher antioxidant activity. Based on the results of current study, $P$. cubeba is a great source of secondary metabolites. Further analysis regarding biological activities of the plant will be conducted soon.

\section{AUTHORS' CONTRIBUTIONS}

Both the authors had contributed equally in performing the assays and writing the manuscript.

\section{COMPETING INTEREST}

The authors declared that they have no conflicts of interest.

\section{REFERENCES}

1. Siddiqui S, Verma A, Rather AA, Jabeen F, Meghavansi MK. Preliminary phytochemical analysis of some important medicinal and aromatic plants. Adv Biol Res 2009;3:188-95.

2. Birt DF. Phytochemicals and cancer prevention: From epidemiology to mechanism of action. J Am Diet Assoc 2006;106:20-1.

3. Shilika S, Vijayalaxmi KK. Phytochemical investigation of extract/ solvent fractions of Piper nigrum Linn. Seeds and Piper betle Linn. Leaves. Int J Pharm Bio Sci 2012;3:344-9.
4. Gayatri N, Sahu RK. Phytochemical evaluation and antioxidant activity of Piper cubeba and Piper nigrum. J Appl Pharm Sci 2011;1:153-7.

5. Sindhu S, Manorama S, Alfamol PM. Preliminary phytochemical analysis and antimicrobial activity of Piper longum L. (Piperaceae). Mintage J Pharm Med Sci 2013;87:21-3

6. Manjulika Y, Sanjukta C, Sharad KG, Geeta W. Preliminary phytochemical screening of six medicinal plants used in traditional medicine. Int J Pharm Pharm Sci 2014;6:539-42.

7. Edeoga HO, Okwu DE, Mbaebie BO. Phytochemical constituents of some Nigerian medicinal plants. Afr J Biotechnol 2005;4:685-8.

8. Rajiv P, Deepa A, Vanathi P, Vidhya D. Screening for phytochemicals and ftir analysis of Myristica dactyloid fruit extracts. Int J Pharm Pharm Sci 2017;9:315-8

9. Varsha H, Sonali S. Studies on qualitative phytochemical analysis of selected species of piper. Int J Life Sci 2014;2:156-8.

10. Eloff JN. Which extractant should be used for the screening and isolation of antimicrobial components from plants? J Ethnopharmacol 1998;60:1-8.

11. Singleton VL, Orthofer R, Raventos RM. Analysis of total phenols and other oxidation substrates and antioxidants by means of folin-ciocalteu reagent. Meth Enzymol 1999;299:152.

12. Lakshman RB. Phytochemical screening, quantitative estimation total phenolics and total flavonoids, anti-microbial evaluation of Cyamopsis tetragonoloba. Int J Res Pharm Biomed Sci 2012;3:1139-42.

13. Kam PC, Liew S. Traditional Chinese herbal medicine and anaesthesia. Anaesthesia 2002;57:1083-9.

14. Kokate CK, Chaudhari GN, Nimbkar AY. Search for Anthelmintics of Plant Origin: Activities of Volatile Principles of Acorus calamus and Piper longum Against Ascaris lumbricoides. Bangkok, Thailand: Asian Symposium on Medicinal Plants and Spices, Conference; 1980. p. 15-9.

15. Hritcu L, Noumedem JA, Cioanca O, Hancianu M, Kuete V, Mihasan M, et al. Methanolic extract of Piper nigrum fruits improves memory impairment by decreasing brain oxidative stress in amyloid beta(1-42) rat model of Alzheimer's disease. Cell Mol Neurobiol 2014;34:437-49.

16. Okudu T, Yoshida T, Hatano T. Food phytochemicals for cancer prevention II. In: Ho CT, Osawa T, Huang MT, Rosen RT, editors. Chemistry and Antioxidative Effects of Phenolic Compounds from Licorice, Tea and Compositae and Labiateae Herbs. Washington, DC: American Chemical Society; 1990. p. 132-43.

17. Tepe B, Sokmen M, Akpulat HA, Sokmen A. Screening of the antioxidant potentials of six Salvia species from Turkey. Food Chem 2006;95:200-4.

18. Ahlem R, Souad I, Beatrice B, Valerie M, Fathi M, Evelyne O, et al. Total phenolic, total flavonoid, tannin content and antioxidant capacity of Halimium halimifolium (Cistaceae). J Appl Pharm Sci 2014;5:52-7.

19. Crozier A, Ashihara H. Clifford MN. Plant Secondary Metabolites and the Human Diet. Oxford. Englend: Blackwell Publishing; 2006. 